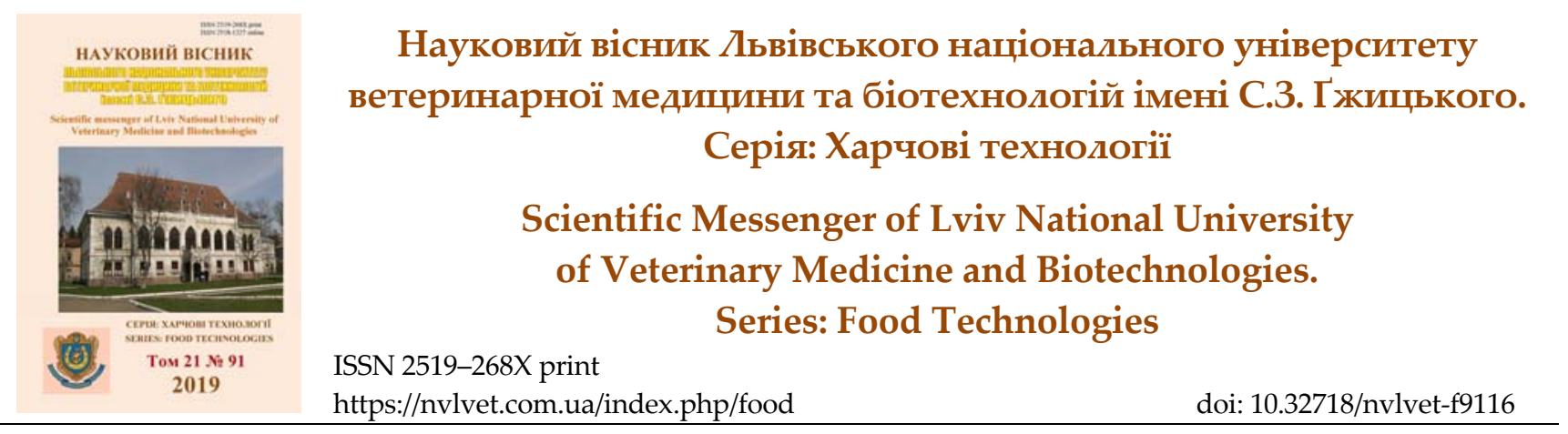

UDC 621.867 .157

\title{
Optimization of the structure of the vibratory feeders with electromagnetic vibrating drive and a combined oscillating system
}

\author{
A.L. Bespalov, I.G. Svidrak, R.Z. Stotsko \\ National University "Lviv Polytechnic”, Lviv, Ukraine
}

Article info

Received 28.01.2019

Received in revised form 04.03 .2019

Accepted 05.03.2019

National University "Lviv Polytechnic", S. Bandera Str., 12, Lviv, 790013, Ukraine.

Tel.: +38-066-229-50-87

E-mail: anatoliq.bespalov@gmail.com

svidrak99@gmail.com,

rostyk03031967@gmail.com
Bespalov, A.L., Svidrak, I.G., \& Stotsko, R.Z. (2019). Optimization of the structure of the vibratory feeders with electromagnetic vibrating drive and a combined oscillating system. Scientific Messenger of Lviv National University of Veterinary Medicine and Biotechnologies. Series: Food Technologies, 21(91), 95-99. doi: 10.32718/nvlvet-f9116

Vibration loading devices are widely used in various branches of mechanical engineering to load piece blanks of automatic machines and automatic lines as well as robotic systems, automated systems and flexible automated production. Vibration devices for transportation and loading of miniature, small and medium-sized products are the most widely used. In the study of vibration transport, one of the most important issues is the study of the dependence of the average transport speed on the parameters of the oscillation of the carrier tray. It is most convenient to conduct a study in dimensionless quantities when expressing the speed of transportation through the speed coefficient, which shows how much the real speed of the part is close to the maximum speed of the transporting surface. For vibration conveyors and vibratory feeders with non-separable transportation parts using modes that are implemented mainly elliptical or asymmetric longitudinal vibrations of the bearing plane. Asymmetric laws of motion of vibration conveyors provide the highest performance in a non-invasive mode of movement of billets, but such conveyors have found a very limited distribution due to the complexity of the implementation of asymmetric vibrations by simple means. To implement the asymmetric laws of oscillation of the working body and thereby increase the speed coefficient used as power sources generators asymmetric types of oscillations, which have a very high cost. Modern production involves the creation of new models of machines with high technical and economic indicators, therefore, improving the efficiency of existing equipment and the development of new schemes of machines is an important task for designers and manufacturers of technological equipment, as the minimum improvement of its technological and operational performance can lead to a tangible economic effect. To solve this problem, the authors developed a new design of vibration hopper feeder, which carries out the transportation of products in the mode without throwing with an asymmetric law of oscillation of the carrier tray when connected directly to the AC network without using an asymmetric pulse generator and conducted an experimental study of its design to determine the speed coefficient during vibration transportation.

Key words: vibrating transportation, speed ratio, vibrating feeder mode without flinging, pneumatic damper, asymmetric oscillation.

\section{Оптимізація структури віброживильників 3 електромагнітним вібраційним приводом і комбінованою коливальною системою}

\author{
А.Л. Беспалов, І.Г. Свідрак, Р.3. Стоцько \\ Національний університет “Львівська політехніка”, м. Львів, Украӥна
}

Вібраційні завантажувальні пристрої отримали широке розповсюдження в різноманітних галузях машинобудування для завантажування штучними заготовками верстатів-автоматів та автоматичних ліній а також робототехнічних систем, автоматизованих комплексів та гнучких автоматизованих виробництв. Найбільше розповсюдження отримали вібраційні пристрої для транспортування та завантаження мініатюрних, дрібних та середніх виробів. При вивченні вібрачійного транспортування одним з найбільш важливих питань є дослідження залежності середньої ивидкості транспортування від параметрів коливання несучого лотка. Зручніше всього проводити дослідження в безрозмірних величинах при вираженні швидкості транспортування через кое- 
фіцієнт швидкості, який показує наскільки реальна швидкість вібротранспортування деталі наближена до максимальної швидкості транспортуючої поверхні. Для вібротранспортерів та віброживильників з безвідривним транспортуванням деталей використовують режими, які реалізуються переважно еліптичними або асиметричними поздовжними коливаннями несучої площини. Найвищу продуктивність в безвідривному режимі переміщення заготовок забезпечують асиметричні закони руху вібраційних транспортерів, але такі транспортери знайтли дуже обмежене розповсюдження завдяки складності реалізації асиметричних коливань простими засобами. Для реалізачії несиметричних законів коливань робочого органу і тим самим збільшення коефіцієнту швидкості використовують у якості джерел живлення генератори несиметричних видів коливань, які мають дуже велику вартість. Сучасне виробництво передбачає створення нових зразків машин з високими техніко-економічними показниками, тому, підвищення ефективності роботи існуючого обладнання і розробка нових схем машин є важливим завданням для проектантів та виробників технологічного обладнання, оскільки мінімальне покращання його технологічних та експлуатаційних показників може привести до відчутного економічного ефекту. Для вирішення поставленої проблеми авторами було розроблено нову конструкцію вібраційного бункерного живильника, щчо здійснює вібротранспортування виробів у безвідривному режимі з несиметричним законом коливання несучого лотка при підключенні його безпосередньо до мережі змінного струму без використання генератора несиметричних імпульсів і проведено експериментальне дослідження його конструкиї з метою визначення коефіцієнту швидкості при вібротранспортуванні.

Ключові слова: вібротранспортування, коефіиієнт швидкості, віброжсивильник, безвідривний режси, пневмодемпфер, асиметричні коливання.

\section{Вступ}

Вібраційні завантажувальні пристрої отримали широке розповсюдження в різноманітних галузях машинобудування для завантажування штучними заготовками верстатів-автоматів та автоматичних ліній а також робототехнічних систем, автоматизованих комплексів та гнучких автоматизованих виробництв.

Досвід розробок та експлуатації вібраційних пристроїв дозволив створити засоби завантаження, які відрізняються простотою конструкції, універсальністю, надійністю і довговічністю роботи, а також економічністю експлуатації. Найбільше розповсюдження отримали вібраційні пристрої для транспортування та завантаження мініатюрних, дрібних та середніх виробів.

При вивченні вібраційного транспортування одним 3 найбільш важливих питань є дослідження залежності середньої швидкості транспортування V від параметрів коливання. Зручніше всього проводити дослідження в безрозмірних величинах при вираженні швидкості транспортування через коефіцієнт швидкості. Тому, одним з основних параметрів, що характеризують досконалість конструкції віброживильника $\epsilon$ так званий коефіцієнт швидкості, який показує наскільки реальна швидкість вібротранспортування наближена до максимальної швидкості транспортуючої поверхні останнього. Режими вібротранспортування поділяються на безвідривні та на режими 3 підкиданням і залежать від величини параметру перевантаження $\xi_{1}$. Безвідривні режими існують при $\xi_{1} \leq 1$, режими 3 підкиданням - при $\xi_{1}>1$. Найбільш досконалими $\epsilon$ режими безвідривні. Тому, зупинимся на розгляді конструкцій, що реалізують такі режими вібротранспортування. Існує декілька напрямків модернізації віброживильників щодо збільшення його коефіцієнта швидкості, одним з яких $є$ підключення електромагнітного приводу живильника до генератора асиметричних коливань. Цей метод найбільш ефективний при застосуванні його до віброживильників 3 безвідривним режимом транспортування.

\section{Матеріал і методи досліджень}

Аналіз останніх публікацій (Lavendel, 1966), в яких розглядаються проблеми створення високоефективних віброживильників та вібротранспортерів, виявив, що для вібротранспортерів та віброживильників з безвідривним транспортуванням деталей використовують режими, які реалізуються переважно еліптичними або асиметричними поздовжними коливаннями несучої площини. Найвищу продуктивність в безвідривному режимі переміщення заготовок забезпечують асиметричні закони руху вібраційних транспортерів, але такі транспортери знайшли дуже обмежене розповсюдження завдяки складності реалізації асиметричних коливань простими засобами. Використання негармонічних коливань значно розширює можливості вібраційних завантажувальних пристроїв, але відомі конструкції таких живильників значно дорожчі за попередні.

В роботі Копилова Н.Г. на основі аналізу кінематичних діаграм конвеєрів визначено, що найбільш вигіднішими законами руху лотка конвеєра є параболічні. Процес вібротранспортування вантажу при пилоподібному законі руху лотка, який апроксимує деякі параболічні закони, дослідили Геккер Ф.Р. і Теміс Ю.M. (Gekker \& Temis, 1970), в роботі яких відзначено складність реалізації пилоподібного закону коливань простими засобами.

Для реалізації несиметричних законів коливань робочого органу i, тим самим, збільшення коефіцієнту швидкості використовують у якості джерел живлення генератори несиметричних видів коливань, які мають дуже велику вартість, або застосовують спеціальні конструкції віброживильників. Віброживильник, який реалізує несиметричні коливання (АС 1144946), для забезпечення такого закону має упори, що закріплені на робочому органі та на основі з можливістю взаємодії між собою. Конструкція цього живильника складна у налагодженні та експлуатації, утворює сильний звуковий фон i, крім цього, має складну і дорогу систему керування.

Таким чином, не зважаючи на достатньо велику кількість досліджень вібраційного транспортування, в перелічених роботах не виявлені шляхи реалізації його оптимальних параметрів, не розроблені констру- 
кції або конструктивні схеми віброживильників, що реалізують найбільш оптимальні режими вібротранспортування. Сучасне виробництво передбачає створення нових зразків машин 3 високими технікоекономічними показниками, тому, підвищення ефективності роботи існуючого обладнання і розробка нових схем машин є важливим завданням для проектантів та виробників технологічного обладнання, оскільки мінімальне покращання його технологічних та експлуатаційних показників може привести до відчутного економічного ефекту.

\section{Результати та їх обговорення}

Для вирішення поставленої проблеми авторами було розроблено нову конструкцію вібраційного бункерного живильника, що здійснює вібротранспортування виробів у безвідривному режимі з несиметрич- ним законом коливання несучого лотка при підключенні його безпосередньо до мережі змінного струму без використання генератора несиметричних імпульсів (Bespalov, 1991). Вібраційний живильник складається 3 робочого органу - чаші 13 днищем 2 (рис. 1), основної пружної системи у вигляді гратчастого гіперболоїдного торсіона, що включає пружини 3, верхній 4 і нижній 5 фланці, додаткової пружної системи у вигляді горизонтально розташованих плоских пружин 6, що з'єднує чашу 13 верхнім фланцем 4 торсіона, електромагнітного віброзбудника, якір 7 якого закріплено до верхнього фланця 4, а електромагніт 8 - до нижнього фланця 5 торсіона, реактивного елемента 9, що також закріплений до нижнього фланця 5 торсіона, нерухомої основи 10 і стояка 11, на які опирається віброживильник через гумові амортизатори 12, 13 і 14, та пневмодемпферів 15.

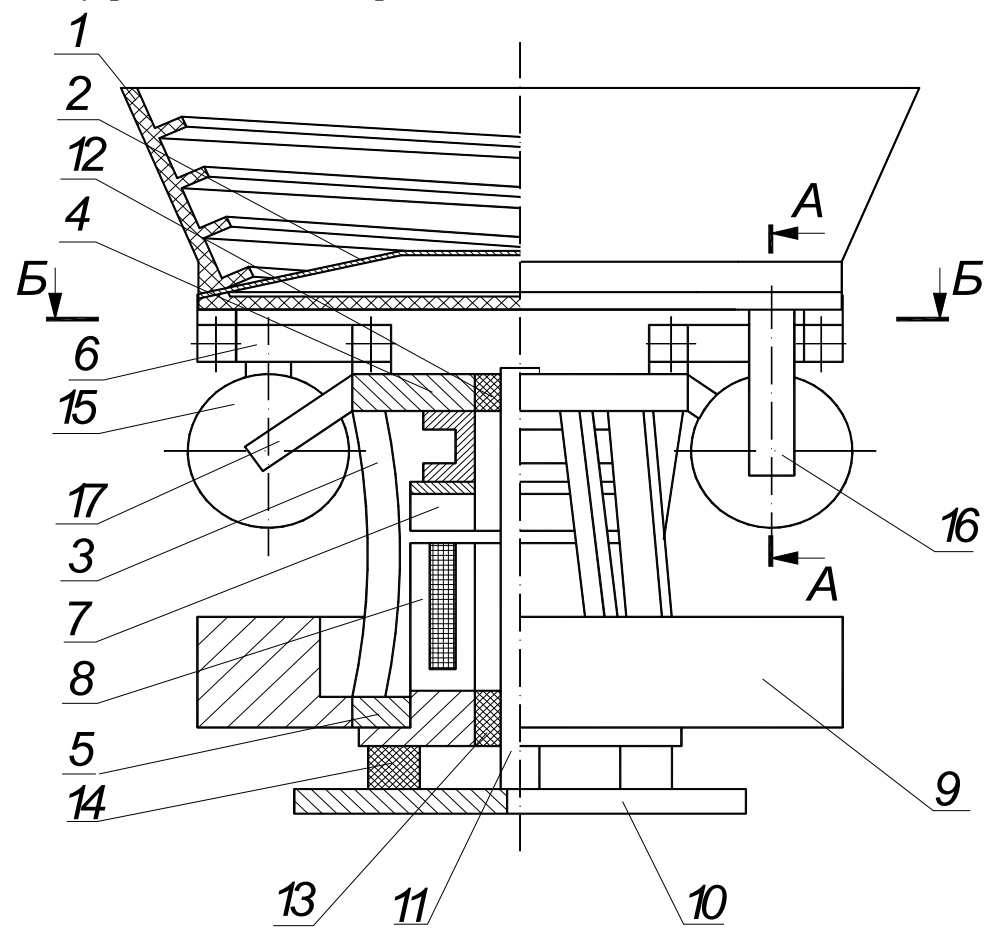

Рис. 1. Конструктивна схема віброживильника

Пневмодемпфер 15 закріплено у вертикальному положенні між чашею 1 і верхнім фланцем 4 торсіона за допомогою верхнього кронштейна 16, що закріплений до чаші 1, і нижнього кронштейна 17, що закріплений до верхнього фланця 4 торсіона Розташування пружин 6 і пневмодемпферів 15 зображено на вигляді зверху по розрізу Б - Б (рис. 2).

Пневмодемпфер 15 (рис. 3). включає корпус, що складається 3 лівої 18 та правої 19 частин, який закріплено до верхнього кронштейна 16, робочого диска 20 3 малими дроселюючими отворами 21 и великими дроселюючими отворами 22, який закріплено до нижнього кронштейна 17, і гумових мембран 23 і 24, які служать для відділення робочих порожнин пневмодемпфера "В" і “Г” один від одного а також від атмосфери. У великих дроселюючих отворах 22 закріплено клапани 25 односторонньої дії.

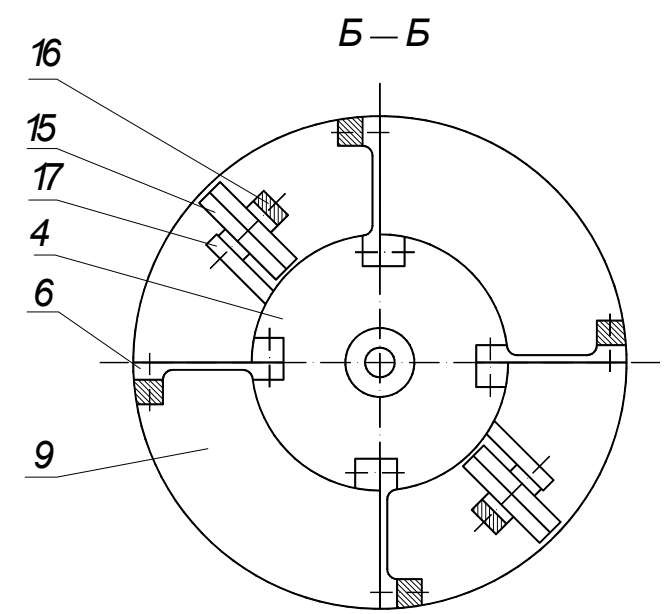

Рис. 2. Схема розташування пружин та пневмодемпферів 


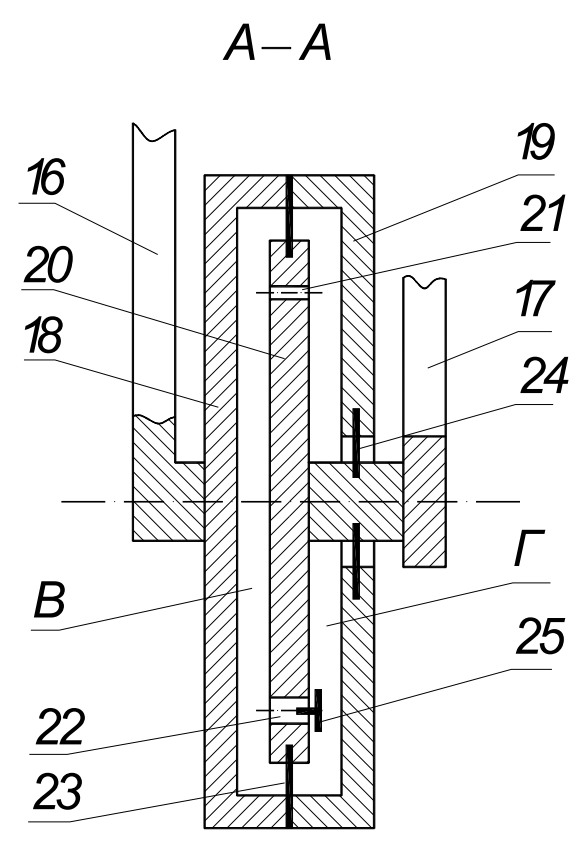

Рис. 3. Конструктивна схема пневмодемпфера

Вібраційний живильник працює таким чином. При включенні віброзбудника верхній 4 і нижній 5 фланці торсіона здійснюють гвинтові коливання у протифазі один відносно одного. Коливання верхнього фланця 4 збуджують коливання робочого органа 1 , закріпленого на ньому за допомогою пружин 6, що утворюють додаткову пружну систему, за рахунок резонансного налагодження цієї системи (власна частота коливань системи - 52...55 Гц при частоті змушуючого зусилля віброзбудника - 50 Гц). Чаша 1 здійснює коливання відносно верхнього фланця 4 торсіона за рахунок деформацій згину пружин 6 i, відповідно, кронштейни 16 і 17, що закріплені на них, також здійснюють протифазні коливання один відносно одного. Корпус 18,19 і диск 20 демпфера також здійснюють протифазні коливання один відносно одного, тому що вони закріплені до кронштейнів 16 і 17. При переміщенні чаші 1 в напрямку транспортування виробів диск 20 зближується з частиною 19 корпуса демпфера. Повітря у порожнині “Г” стискається, а в порожнині “В” утворюється розрідження. Клапани 25 закриваються i повітря переходить 3 порожнини “Г” до порожнини “В” тільки через отвори 21, які мають малий прохідний переріз. Створюється опір переміщенню чаші 1 відносно фланця 4, що зменшує швидкість цього переміщення і збільшує час цього півперіоду коливання. При наступному півперіоді коливання, коли чаша 1 рухається у зворотному напрямку, диск 20 зближується із частиною 18 корпуса демпфера. Повітря у порожнині "В" стискається, а в порожнині "Г" утворюється розрідження. Клапани 25 відкриваються і повітря переходить 3 порожнини "В" до порожнини "Г" як через отвори 21, так і через отвори 22, які мають великий прохідний переріз. В цьому випадку опір переміщенню чаші 1 відносно фланця 4 в багато разів зменшується, що майже не зменшує швидкості цього переміщення, і час цього півперіоду коливання менше часу робочого півперіоду. Таким чином створюється несиметричний закон руху робочого органу - чаші 1 віброживильника при симетричному законі змушених коливань верхнього 4 і нижнього 5 фланців торсіону. Змінюючи співвідношення площ прохідних перерізів малих і великих дроселюючих отворів при налагодженні пневмодемпфера, можна отримати коливання чаші з різними степенями відхилення від симетричності, що розширює технологічні можливості такого віброживильника.

Розміщення демпферів у вертикальному положенні між чашею і верхнім фланцем торсіона дозволяє не тільки отримати несиметричний закон коливання чаші в напрямку переміщення виробів, що транспортуються, але й покращати демпфуючу здатність пневмодемпферів, спростити їх налагодження і підвищити стабільність їх роботи, що в кінцевому результаті також впливає на стабільність роботи віброживильника в цілому.

При вертикальному розташуванні демпфера робочі проміжки між його корпусом і диском залишаються завжди стабільними, незалежно від завантаження чаші живильника деталями чи виробами, тому що жорсткість додаткової пружної системи у вигляді радіально розташованих плоских пружин в напрямку вертикальної осі дуже велика і вертикальні переміщення чаші відносно верхнього фланця торсіона практично відсутні. Крім того, таке розташування демпфера дає можливість використовувати горизонтальну складову коливань для його роботи, що дає змогу отримати значний демпфуючий ефект, що в свою чергу дозволяє створювати великі зсуви фаз між складовими коливань, що важливе при налагодженні живильника для роботи у необхідному режимі.

Таким чином, розміщення пневмодемпферів у вертикальному положенні між чашею і верхнім фланцем торсіона дозволяє отримати великі зсуви фаз між складовими коливань чаші, що спрощує виготовлення і налагодження таких демпферів, крім того, таке розташування робить систему нечутливою до зміни завантаження чаші виробами, що підвищує стабільність роботи віброживильника такої конструкції.

Були проведені експериментальні дослідження на дослідному взірці розробленої конструкції віброживильника без наявності пневмодемпферів і зі встановленими пневмодемпферами для визначення величин коефіцієнтів швидкості при різних амплітудах коливань несучої поверхні при безвідривних режимах вібротранспортування для порівняння цих результатів. Дослідження проводились при вібротранспортуванні деталей циліндричної форми діаметром 8 мм і довжиною 20 мм.

\section{Висновки}

Таким чином, використання у конструкції віброживильника демпферів 3 додатковими отворами i клапанами односторонньої дії, а також додаткової пружної системи, дозволяє отримати несиметричний закон коливань його робочого органу - чаші при простому підключенні електромагнітного віброзбудника в мережу (напряму - 100 Гц, або через діод - 50 Гц) 
без використання спеціальних генераторів імпульсів, які являють собою складні пристрої, що мають велику вартість. Це дозволяє при всіх інших рівних параметpax збільшити коефіцієнт швидкості i, тим самим, збільшити продуктивність живильника на 20...30\% при безвідривних режимах вібротранспортування виробів.

Перспективи подальших досліджень. На даному дослідному взірці віброживильника необхідно провести більш широкі експериментальні дослідження для різних конфігурацій деталей та при різних величинах асиметричності коливань чаші віброживильника.

\section{References}

Lavendel, Je.Je. (1966). Optimal'nyj zakon kolebanija lotka s rezonansnym privodom pri bezotryvnoj vibrotransportirovke detalej. Sbornik "Dinamika mashin" (in Russian).

Gekker, F.R., \& Temis, Ju.M. (1970). Vibrotransportirovka pri piloobraznom zakone dvizhenija lotka. Izvestija vuzov. Mashinostroenie, 2, 98-101 (in Russian).

Bespalov, A.L. (1991). Vibracionnyj pitatel'. Avtorskoe svidetel'stvo № 1648859. Bjulleten' izobretenij, 18 (in Russian). 